\title{
An Overview of Synthesized Bacterial Cellulose Nanocomposites for Biomedical Applications
}

\author{
Muhammad Wasim*1, Muhammad Mushtaq ${ }^{1}$, Saifullah Khan ${ }^{2}$ and Abdul Salam ${ }^{3}$ \\ ${ }^{1}$ Key Laboratory of Eco Textiles, Jiangnan University, Wuxi, China \\ ${ }^{2}$ Department of Textiles Engineering, BUITEMS, Quetta, Pakistan \\ ${ }^{3}$ Department of Textiles \& Clothing, National Textile University (Karachi Campus), Karachi, Pakistan \\ *Corresponding author: Muhammad Wasim, Key Laboratory of Eco Textiles, Jiangnan University, Wuxi, China
}

\section{ARTICLE INFO}

Received: April 17, 2020

Published: 幽 April 28, 2020

Citation: Muhammad Wasim, Muhammad Mushtaq, Saifullah Khan, Abdul Salam. An Overview of Synthesized Bacterial Cellulose Nanocomposites for Biomedical Applications. Biomed J Sci \& Tech Res 27(2)-2020. BJSTR. MS.ID.004483.

\section{ABSTRACT}

The bacterial cellulose (BC) is a three-dimensional structure of fibrils, which can be easily modified by the incorporation of different type of nanoparticle to make it nanocomposite for biomedical applications. The BC has great potential in terms of water holding capacity, therefore, it can be used as a candidate for drug delivery, including the treatment of injuries, burn wounds, bone \& tissue engineering as well as antibacterial material among others. The present development of this innovation into the medical field shows huge potential for nanoparticles loaded bacterial cellulose to turn into a piece of the regular application for several treatments. Conclusively, nanoparticles loaded bacterial cellulose have the great potential to be customizable, the uses of BC/ Nanoparticles in the medical field are infinite.

Keywords: Bacterial Cellulose; Nanoparticles; Wound Dressing; Drug Delivery; Biomedical

\section{Introduction}

The different working organizations, government offices at all levels progressively demand the biodegradable materials, to minimize the ecological effect created by the present way of life. Characteristic cellulose-based materials (which are the more rich polysaccharides in nature and incorporate wood, hemp, cotton, among others) have been utilized for quite a while by our general public for these applications because of their wide accessibility, biodegradability, and sustainability [1-3]. Similarly, the investigation and utilization of bacterial cellulose is generally the latest development. Regardless of sharing thoughts, the bacterial cellulose is quite different from the vegetable cellulose. The fibers which are obtained by plants composed of lignin, hemicelluloses, $40 \%$ to $70 \%$ cellulose, and gelatin. In addition, bacterial cellulose is encompassed to unadulterated cellulosic nanofibers, showing extraordinary immaculateness as well as good quality, exclusive of demanding consequent refining medications [4]. However, due to the special attributes, bacterial cellulose (BC) widely considered in recent research on biomedical applications [5].

Bacterial cellulose which demonstrates web structure, prepared by particular sorts of active bacteria, for example, Salmonella,
Sarcina ventriculi, Acetobacter, Azotobacter, Gluconacetobacter, and Pseudomonas [6]. The most efficient and widely used bacteria for the production of bacterial cellulose are considered $G$. hansenii, G. pasteurianus, and G. xylinum [7]. The cellulose growth begins when microbes polymerize glucose buildups into linear $\beta-1$, fourgluconic network with creating a prepositive discharge designed chains. Moreover, microbe accumulated and solidify the chains which go to made strips [8]. Besides, procedure prompts with an arrangement of cognizant thin-film, three-dimensional web of cellulosic material adjusted, which corresponding to the outside fluid medium as illustrating Figure 1. This web-like structure known as a pellicle. Also, its geometry controlled by the intraand intermolecular hydrogen-holding system, hydrophobic and van der Waals linked characteristics [9]. Bacterial cellulose has a crystallographic structure, with up to $90 \%$ level of crystallinity [10]. The few hydroxyl networks on bacterial cellulose surface make it a hydrophilic composite that can be used as a wound dressing [11]. Bacterial cellulose nanofibers have a diameter of approximately 20$100 \mathrm{~nm}$ and show a surface zone better than that of cellulose which obtained by plants [12]. 


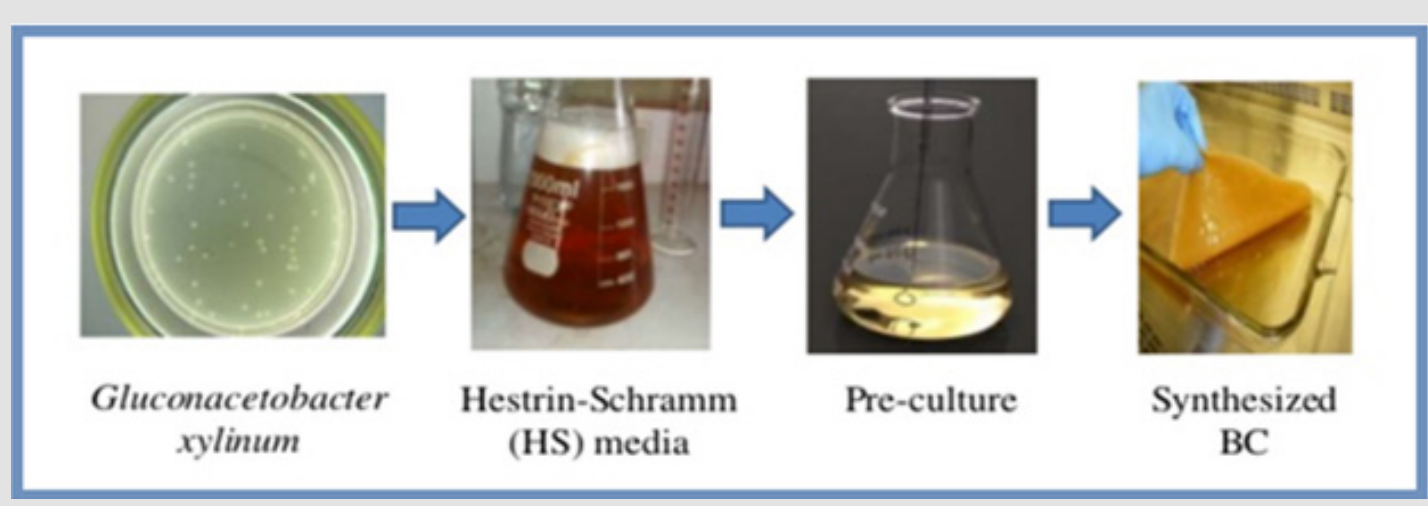

Figure 1: Preparation of bacterial cellulose to follow 6 days culture process.

It has been investigated that mechanical properties of bacterial cellulose, yielding a normal elasticity of $241.42 \pm 21.86 \mathrm{MPa}$, the most elongation of $8.21 \pm 3.01 \%$ with $6.86 \pm 0.32 \mathrm{GPa}$ value of Young's modulus [13]. The functional behavior, elasticity with incredible mechanical characteristics of bacterial cellulose (BC) clearly identified as sufficient for specific uses previously. Moreover, the current requirement for bacterial cellulose items encompasses better characteristics that full-fill the needs in several fields turns out to be progressively clear. The advanced bacterial cellulose composites are resultant of the utilization of nano particles, which are enrich with required properties. However, BC has a nanofibers structure, and such type of advance materials encompass with connection of two nano based materials, known as nanocomposites. Our review study reveals that the synthesized nanoparticles permit the incorporation of practical nano reinforcements, nanofillers, and advance developments into bacterial cellulose, with a specific enthusiasm on those developed materials without upsetting the structure of bacterial cellulose. The nanoparticles which are used to synthesis bacterial cellulose nanocomposite are considered, encompass characteristics with their uses in medical applications.

\section{Uses in Medical Field}

Similarly, as different polysaccharides were prepared for biomedical applications, bacterial cellulose as well found a material in which it has a tendency to be considered [14]. Light tissueengineered materials are considering with high enthusiasm for the healing of burns wound, injuries, and tissue substitution. Another recent approach is a nanocomposite of bacterial cellulose with copper and zinc oxide nanoparticles, which provide ultraviolet resistance as well as antibacterial characteristics for medical application which could be utilized for wound dressing [15]. Polyvinyl acetate in a recent study of research considered as a hydrophilic biocompatible polymer, which has considerable properties for biomedical applications. The nanocomposite formation of polyvinyl acetate and bacterial cellulose shows a better lifecycle and biocompatibility with magnificent physical characteristics. It has been explored that grown BC/PVA nanocomposites can supplant cardiovascular tissues because BC/ PVA shows comparative attributes to cardiovascular tissues [16]. There is a technique of freezing-thaw method which sets up a BC/ PVA layer as an artificial cornea substitution.

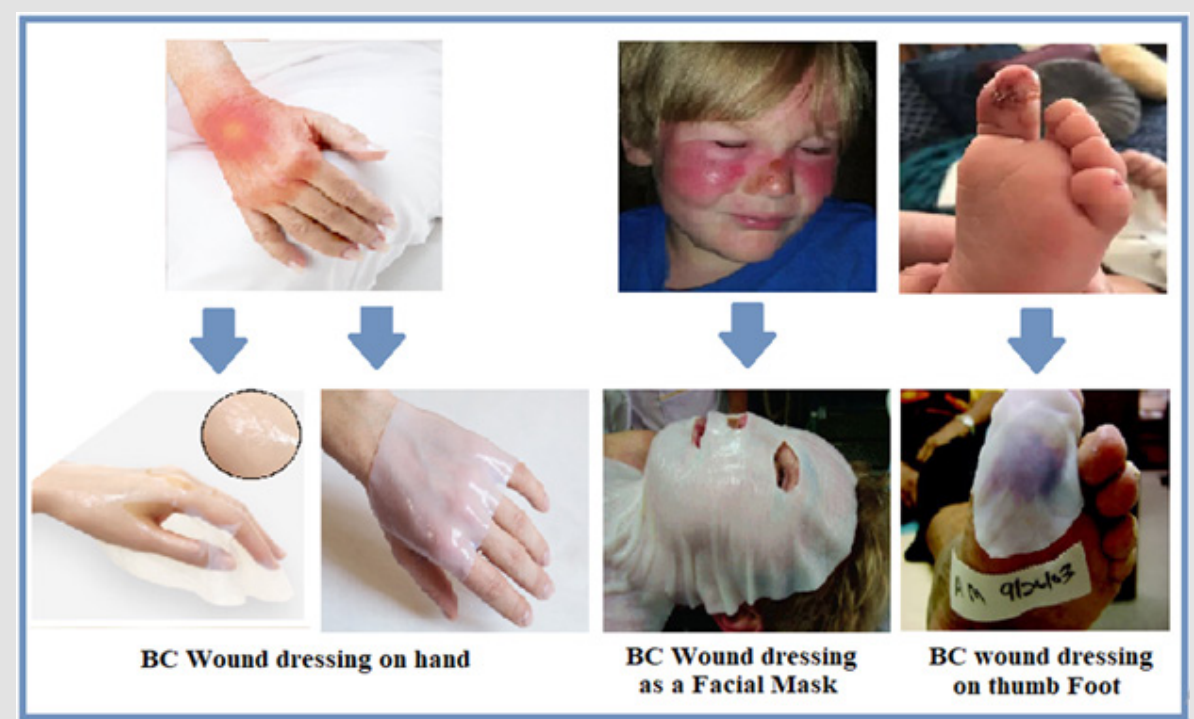

Figure 2: Bacterial cellulose nanocomposite application for wound dressing. 
Meanwhile, its, outcomes demonstrated that BC/PVA nanocomposite enriched with excellent water absorbency, good light transmit ability, ultra-violate absorbency, good thermal property, and excellent mechanical characteristic. The common uses encompass the preparation of $\mathrm{BC} /$ polyethylene glycol (PEG) nanocomposites, demonstrated good thermal and mechanical characteristics because of their profoundly interlinked structure. Additionally, they displayed great cell attachment and multiplication properties, making them appropriate for the application of wound dressing and tissue-building [17], as shown in Figure 2. The blend of bacterial cellulose with different added substances offers to ascend to composite for utilization of bone and ligament tissue building. The blending of HAp and Collagen build-up a common bone in an efficient way. At that point, provide extraordinary osteoconductive and bioactivity of Hap. Further, it tends to be functional for tissue building related to bacterial cellulose [18]. The recently prepared BC/HAp nanocomposites with the help culture medium mineral phasing and $\mathrm{CMC}$, in which CMC expansion caused a half decrease in the fibers diameter [19].

The researcher exhibited the biocompatibility as well as cell suitability for prepared materials which utilizing cell cultures of HEK. It likewise has been recommended that the blend of collagen and BC, developed flexible layers which indicated osteoblastic differentiation in vitro [20]. The composite of bacterial cellulose by acetosulfation, confirming cell suitability, cancer prevention agent characteristics, and hemocompatibility of the as-built nanocomposite [21]. Moreover, bacterial cellulose web structure may be utilized on the beginning stage to particular assignments, for example, bone recovery, which demonstrates a micro-sized pores nanocomposite. However, to overcome this issue, it has been set porogen materials like paraffin wax circles and starch of different grain measures in the developing cultures of Acetobacter xylinum [22]. Likewise, detailed that smooth muscle cells moved to the samples with bigger pores diameter across. They encompass 300-500 $\mu \mathrm{m}$ paraffin wax microspheres added to BC medium which enhances cell infiltration, by expanding the pore size and presenting cells of osteoprogenitor [23].

So, these types of composites might be of enthusiasm for bone recovery, and it could support osteoblast ingrowth with mineralized tissue developing. An assortment of characteristic materials and manufactured polymers are being prepared, comprising drug, development variables, peptides, as well as different bioactive materials to improve wound healing [24]. Specifically, the utilization of bacterial cellulose as a wound dressing indicated that bacterial cellulose-dressings keep away to moist condition and take into consideration drugs or other bioactive materials to keep in touch with the harmed region [25]. These characteristics can be accomplished by adjusting the specific attributes of $\mathrm{BC}$ through basic changes, compound responses, or basically to make the physical blending of structures [26]. Bacterial cellulose nanocomposites have likewise been utilized as medication conveyance frameworks. For example, a dry BC film submerged in benzalkonium chloride (antibacterial) accomplished a $0.116 \mathrm{mg} /$ $\mathrm{cm} 2$ medication stacking limit. The outcomes (S. aureus and E. coli) indicated that the medication effects remain up to 24 hours against polluted injuries [27].

The doped bacterial cellulose films with glycerin for topical and transdermal medication conveyance applications has been reported [28]. The moisturizing effect is obtained by glycerin , which helpful for sores with dryness, for example, atopic dermatitis and psoriasis. So, the notable tablet excipient is Hydroxypropyl methylcellulose (HPMC) [29]. In this manner, a BC/HPMC composite has been prepared by couture medium with addition of HPMC. The results against utilizing the bacterial cellulose with other materials as tablet excipients illustrate excellent outcomes. So, its recommending that bacterial cellulose is an excellent candidate for carry to utilization of small medication atoms. Therefore, to supplement this point, bacterial cellulose is by all accounts a perfect base material because of its ability to hold water. Another approach, BC encompass polyacrylic corrosive for drug delivery framework. However, composite indicated a pH-delicate arrival of BSA (bovine serum albumin, a model protein) with intestinal $\mathrm{pH}$ values. Moreover, such a composite represent the bigger pores charged more bovine serum albumin.

\section{Conclusion}

The synthesized nanoparticles loaded bacterial cellulose (BC) can be used as an excellent candidate for several applications in the field of biomedicine; as drug delivery, including the treatment of injuries, burn wounds, bone \& tissue engineering as well as antibacterial material among others. The present development of this innovation in the medical field shows huge potential for nanoparticles loaded bacterial cellulose to turn into a piece of the regular application for several treatments. Conclusively, nanoparticles loaded bacterial cellulose have the great potential to be customizable, the uses of BC/Nanoparticles in the medical field are infinite.

\section{References}

1. Coughlan MP, Carvalho ALA, Leite SGF, Pereira N (1985) Cellulases: production, properties and applications. Biochem Soc Trans 13(2): 405406.

2. Sánchez C (2009) Lignocellulosic residues: biodegradation and bioconversion by fungi. Biotechnology advances 27(2): 185-194.

3. Stark NM (2016) Opportunities for cellulose nanomaterials in packaging films: A review and future trends. Journal of Renewable Materials 4(5): 313-326.

4. Gamstedt EK (2016) Moisture induced softening and swelling of natural cellulose fibres in composite applications. Materials Science and Engineering 139.

5. Bäckdahl H, Helenius G, Bodin A, Nannmark U, Johansson BR, et al. (2006) Mechanical properties of bacterial cellulose and interactions with smooth muscle cells. Biomaterials 27(9): 2141-2149. 
6. Shoda M, Y Sugano (2005) Recent advances in bacterial cellulose production. Biotechnology and Bioprocess Engineering 10(1): 1.

7. Falomo $O O$ (2016) In vitro evaluation of resistant starch usingcorn. Southern Illinois University at Carbondale.

8. Czaja WK, Young DJ, Kawecki M, Brown RM, et al. (2007) The future prospects of microbial cellulose in biomedical applications. Biomacromolecules 8(1): 1-12.

9. Koizumi S, Yue Z, Tomita Y, Kondo T, Iwase H, et al. (2008) Bacterium organizes hierarchical amorphous structure in microbial cellulose. The European Physical Journal E 26(1): 137-142.

10. Lee KY, Buldum G, Mantalaris A, Bismarck A (2014) More than meets the eye in bacterial cellulose: biosynthesis, bioprocessing, and applications in advanced fiber composites. Macromolecular bioscience 14(1): 10-32.

11. Gelin K, Bodin A, Gatenholm P, Mihranyan A, Edwards K, et al. (2007) Characterization of water in bacterial cellulose using dielectric spectroscopy and electron microscopy. Polymer 48(26): 7623-7631.

12. Chi K, Catchmark JM (2017) The influences of added polysaccharides on the properties of bacterial crystalline nanocellulose. Nanoscale 9(39): 15144-15158.

13. Grande CJ, Torres FG, Gomez CM (2008) Morphological characterisation of bacterial cellulose-starch nanocomposites. Polymers and Polymer Composites 16(3): 181-185.

14. Picheth GF, Pirich CL, Sierakowski MR, Woehl MA, Sakakibara CN, et al. (2017) Bacterial cellulose in biomedical applications: A review. International journal of biological macromolecules 104(Pt A): 97-106.

15. Wasim M, Khan MR, Mushtaq M, Naeem M, Han M, et al. (2020) Surface Modification of Bacterial Cellulose by Copper and Zinc Oxide Sputter Coating for UV-Resistance/Antistatic/Antibacterial Characteristics. Coatings 10(4): 364.

16. Millon LE, Wan WK (2006) The polyvinyl alcohol-bacterial cellulose system as a new nanocomposite for biomedical applications. Journal of Biomedical Materials Research Part B: Applied Biomaterials 79(2): 245253.

17. Cai Z, Kim J (2010) Bacterial cellulose/poly (ethylene glycol) composite: characterization and first evaluation of biocompatibility. Cellulose 17: 83-91.

18. Wan YZ, Huang Y, Yuan CD, Raman S, Zhu Y, et al. (2007) Biomimetic synthesis of hydroxyapatite/bacterial cellulose nanocomposites for biomedical applications. Materials Science and Engineering: C 27(4): 855-864.

19. Grande CJ, Torres FG, Gomez CM, Bañó MC (2009) Nanocomposites of bacterial cellulose/hydroxyapatite for biomedical applications. Acta Biomaterialia 5(5): 1605-1615.

20. Saska S, Teixeira LN, Oliveira PT, Gaspar AMM, Ribeiro SJL, et al. (2012) Bacterial cellulose-collagen nanocomposite for bone tissue engineering. Journal of Materials Chemistry 22(41): 22102-22112.

21. Palaninathan V, Raveendran S, Rochani AK, Chauhan N, Sakamoto Y, et al. (2018) Bioactive bacterial cellulose sulfate electrospun nanofibers for tissue engineering applications. Journal of tissue engineering and regenerative medicine 12(7): 1634-1645.

22. Bäckdahl H, Esguerra M, Delbro D, Risberg B, Gatenholm P (2008) Engineering microporosity in bacterial cellulose scaffolds. Journal of tissue engineering and regenerative medicine 2(6): 320-330.

23. Zaborowska M, Bodin A, Bäckdahl H, Popp J, Goldstein A, et al. (2010) Microporous bacterial cellulose as a potential scaffold for bone regeneration. Acta biomaterialia 6(7): 2540-2547.

24. Bergstrom N, Horn SD, Smout RJ, Bender SA, Ferguson ML, et al. (2005) The National Pressure Ulcer Long-Term Care Study: outcomes of pressure ulcer treatments in long-term care. Journal of the American Geriatrics Society 53(10): 1721-1729.

25. Czaja W, Krystynowicz A, Bielecki S, Brown RM (2006) Microbial cellulose-the natural power to heal wounds. Biomaterials 27(2): 145151.

26. Sulaeva I, Henniges U, Rosenau T, Potthast A (2015) Bacterial cellulose as a material for wound treatment: Properties and modifications. A review. Biotechnology advances 33(8): 1547-1571.

27. Araújo IM, Silva RR, Pacheco G, Lustri WR, Tercjak A, et al. (2018) Hydrothermal synthesis of bacterial cellulose-copper oxide nanocomposites and evaluation of their antimicrobial activity. Carbohydrate polymers 179: 341-349.

28. Sharma C, Bhardwaj NK (2019) Bacterial nanocellulose: Present status, biomedical applications and future perspectives. Materials Science and Engineering: C 104: 109963.

29. Hardy JG, Lee JY, Schmidt CE (2013) Biomimetic conducting polymerbased tissue scaffolds. Current opinion in biotechnology 24(5): 847-854.

ISSN: 2574-1241

DOI: $10.26717 / B J S T R .2020 .27 .004483$

Muhammad Wasim. Biomed J Sci \& Tech Res

CC (P) This work is licensed under Creative Commons Attribution 4.0 License

Submission Link: https://biomedres.us/submit-manuscript.php

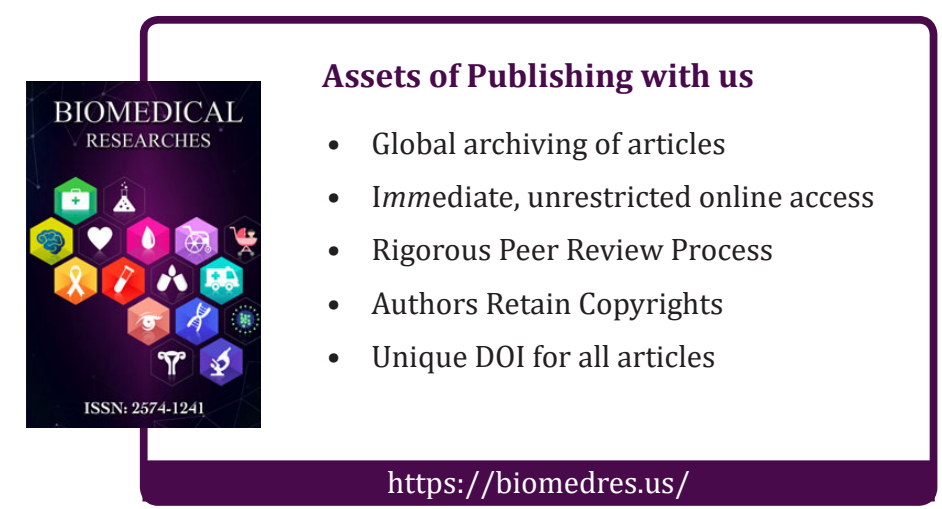

